\title{
ЦИФРОВИЙ МАРКЕТИНГ ЯК ФАКТОР УСПІХУ НА РИНКУ ВЕТЕРИНАРНИХ ІМУНОБІОЛОГІЧНИХ ПРЕПАРАТІВ УКРАЇНИ
}

\author{
DIGITAL MARKETING AS SUCCESS FACTOR \\ AT UKRAINIAN MARKET OF VETERINARY \\ IMMUNOBIOLOGICAL PREPARATIONS
}

\author{
Коблянська Інна Ігорівна \\ кандидат економічних наук, доцент, \\ Сумський національний аграрний університет \\ ORCID: https://orcid.org/0000-0002-7844-9786 \\ Лукаш Світлана Миколаївна \\ кандидат економічних наук, доцент, \\ Сумський національний аграрний університет \\ ORCID: https://orcid.org/0000-0003-1948-7683 \\ Бірюков Олексій Олексійович \\ магістрант, \\ Сумський національний аграрний університет \\ ORCID: https://orcid.org/0000-0001-5931-9698
}

\author{
Koblianska Inna, Lukash Svitlana, Biriukov Oleksiy \\ Sumy National Agrarian University
}

\begin{abstract}
В умовах інтенсифікації конкуренції та пандемічних обмежень, особливо актуальним є дослідження перспектив та доцільності (з точки зору формування конкурентних переваг) використання цифрових технологій у маркетингу ветеринарних продуктів. У статті досліджено стан конкуренції на вітчизняному ринку ветеринарних імунобіологічних препаратів та визначено трійку лідерів. Використовуючи відкриті дані досліджено динаміку показників фрінансово-господарської діяльності ідентифікованих лідерів ринку та встановлено, що для більшості з них 2020 рік характеризувався негативними тенденціями динаміки фінансово-господарських результатів. Аналізуючи маркетингові аспекти діяльності підприємств, встановлено різний рівень застосування цифрових технологій: окремі підприємства мають низький рівень активності у соціальних мережах; одне підприємство має непрацюючий сайт; а підприємство, що демонструє позитивну динаміку фрінансово-господарських показників, використовує широкий спектр цисрових інструментів (інтернет-магазин, розвинена мережа сайтів-дистриб'юторів, зворотні фрорми на сайті, професійно розроблений сайт та ін.). Наголошено на необхідності використання професійних послуг у розробці та підтримці роботи сайтів як запоруки успішного розвитку підприємства на ринку ветеринарних імунобіологічних препаратів України.
\end{abstract}

Ключові слова: конкуренція, ринок ветеринарних препаратів, цифровий маркетинг, SEO-аналіз, електронна торгівля.

В условиях интенсификации конкуренции и пандемических ограничений, особенно актуальным является исследование перспектив и целесообразности (с точки зрения фрормирования конкурентных преимуществ) использования цифровых технологий в маркетинге ветеринарных продуктов. В статье исследовано состояние конкуренции на отечественном рынке ветеринарных иммунобиологических препаратов и определена тройка лидеров. Используя открытые данные, исследована динамика показателей фринансово-хозяйственной деятельности идентисрицированных лидеров рынка и установлено, что для большинства из них 2020 год характеризовался негативными тенденциями динамики фринансово-хозяйственных результатов. Анализируя маркетинговые аспекты деятельности предприятий, установлен разный уровень применения цисровых технологий: отдельные предприятия имеют низкий уровень активности в социальных сетях; одно предприятие имеет неработающий сайт; а предприятие, демонстрирующее положительную динамику фринансово-хозяйственных показателей, использует широкий спектр цифровых инструментов (интернет-магазин, развитая сеть 
сайтов-дистрибьюторов, обратные фрормы на сайте, профессионально разработанный сайт и др.). Отмечено необходимость использования профессиональных услуг в разработке и поддержке работы сайтов как залог успешного развития предприятия на рынке ветеринарных иммунобиологических препаратов Украины.

Ключевые слова: конкуренция, рынок ветеринарных препаратов, цифровой маркетинг, SEO-анализ, электронная торговля.

In the conditions of intensification of competition and pandemic restrictions, research of prospects and expediency (from the point of view of formation of competitive advantages) of use of digital technologies in marketing of veterinary products is especially actual. The article examines the state of competition in the Ukrainian market of veterinary immunobiological drugs and identifies three leaders. Using open data, the dynamics of financial and economic performance of identified market leaders was studied and it was found that for most of them 2020 was characterized by negative trends in the dynamics of financial and economic results. Against the background of the fact that two state-owned enterprises show negative dynamics of financial results, significantly increasing short-term liabilities against the background of low asset growth, the market leader demonstrates significant positive dynamics of most indicators, especially: net income $(+31.08 \%)$; net profit $(+317.02 \%)$; gross profit $(+169.83 \%)$; return on equity $(+$ 28 points); return on assets (+ 19 points); unfinished capital investments (+ 44.28\%); equity (+ 68.39\%); assets (+ $30.44 \%$ ). Analyzing the marketing aspects of enterprises functioning, different levels of application of digital technologies have been found: some enterprises have a low level of activity in social networks; one company has a broken site; and the company, which demonstrates the positive dynamics of financial and economic indicators, uses a wide range of digital tools (online store, developed network of distribution sites, reverse communication forms at the site, professionally designed site, etc.). Using Semrush tools, we analyzed the traffic dynamics and keywords of competing sites and found that the market leader has significantly higher traffic, which is the result of well-chosen keywords and a professionally designed site. The results show that an integral part of the success of digital marketing is the proper work on the analysis and optimization of the site using SEO tools (Search Engine Optimization). Emphasis is placed on the need to use professional services in the development and maintenance of sites as a guarantee of successful development of the enterprise in the market of veterinary immunobiological drugs in Ukraine.

Keywords: competition, market of veterinary drugs, digital marketing, SEO-analysis, e-commerce.

Постановка проблеми. Ринок ветеринарних препаратів у світі є досить привабливим. Не виключенням $€$ й вітчизняний ринок, який, одночасно, має й такі особливості: досить інтенсивна конкуренція (спричинена наявністю як вітчизняних, так і закордонних виробників, наявністю різних найменувань препаратів 3 однією діючою речовиною), високий рівень тінізації та значна частка контрасрактної продукції, гарні конкурентні позиції вітчизняних виробників та ін. [1; 3]. Український ринок ветеринарних засобів постійно розширюється і розвивається, поповнюється новими асортиментними позиціями та учасниками. Це призводить до інтенсифрікації конкуренції, спонукає виробників до пошуку нових стратегій у виробничій, науково-дослідній та маркетинговій діяльності. В умовах обмежень, спричинених пандемією, в усіх галузях спостерігається трансорормація традиційних стратегій та способів маркетингу зі збільшенням ролі цифррових технологій у комунікаціях зі споживачами, збуті продукції. Наявні результати аналітичних досліджень засвідчують суттєве зростання обсягів інтернет- торгівлі навіть у галузях, що традиційно реалізують продукцію офр-лайн [8]. Отже, актуальним є дослідження перспектив та доцільності (з точки зору формування конкурентних переваг) використання цифрових технологій у маркетингу і на ринку ветеринарних препаратів.
Аналіз останніх досліджень і публікацій. Дослідження щодо стану конкуренції та чинників конкурентоспроможності на вітчизняному ринку ветеринарних препаратів $\epsilon$ нечисленними. Загалом, результати наявних досліджень І. Бушуєвої та Н. Борисенко [1], $€$. Гальчинської та Н. Сорокіної [2], Г. Гарвас та В. Колодійчук [3], колективу авторів під керівництвом А. Немченко [6] свідчать про те, що ринок ветеринарних препаратів $€$ досить розгалуженим та містить різні сегменти, в яких фрормуються свої лідери.

Аналізуючи чинники конкурентоспроможності, Г. Гарвас та В. Колодійчук [3] акцентують увагу на необхідності забезпечення відповідності виробництва вимогам належної виробничої практики - Good Manufacturing Practice (GMP). Вченими також визначено конкурентні фрактори, важливі 3 точки зору споживачів: швидкість дії ветеринарного препарату (ефективність) (оцінена на 5 балів 35 ), безпечність для тварин та власників (4 бали), зручність у застосуванні (лікарська срорма) та привабливість дизайну (по 4 бали) [3]. Вчені І. Бушуєва та Н. Борисенко відзначають, що конкурентними перевагами вітчизняних виробників, порівняно з закордонними, $€$ невисока ціна та можливість прямої співпраці з замовниками [1]. Водночас, маркетинговим аспектам конкурентоспроможності суб'єктів 
ринку ветеринарних імунобіологічних препаратів приділено недостатньо уваги. Значення електронної комерції на ринку ветеринарних препаратів розглянуто в дослідженні Н. Єремєєвої та О. Зозульова [4], де виділено особливості електронної комерції та наголошено на тому, що реклама та консультування є перспективними інструментами розвитку електронної торгівлі на ринку ветеринарних препаратів. Водночас, цифровий маркетинг не обмежується електронною торгівлею, рекламою та консультуванням, а отже необхідними $€$ подальші дослідження в цій сорері.

Метою статті $€$ визначення ролі цифрового маркетингу як засобу підвищення конкурентоспроможності підприємства на ринку ветеринарних імунобіологічних препаратів. Досягнення цієї мети обумовлює необхідність вивчення стану конкуренції на ринку, виділення головних гравців та тенденцій їх розвитку, аналізу застосування ними цифрових технологій у маркетингу.

Виклад основного матеріалу. Аналіз ринку ветеринарних імунобіологічних препаратів України та виділення лідерів здійснено відносно вітчизняних виробників (виробник препарату зареєстрований в Україні) за даними «Переліку ветеринарних імунобіологічних препаратів, що зареєстровані в Україні станом на 13.04.2021 р.» [7]. Передусім, було досліджено кількість дійсних реєстраційних посвідчень у розрізі власників реєстраційного посвідчення (фактично, це дозволяє ідентифрікувати розробника препарату). Отже, у Переліку [7] наявні 34 вітчизняних власника реєстраційних свідоцтв. Із загальної кількості представлених у Переліку препаратів (603), 158 виробляються в Україні та $€$ вітчизняними розробками. Лідером вітчизняного сегменту ринку розробки ветеринарних імунобіологічних препаратів $€$ ТОВ Біотестлаб із кількістю власних зареєстрованих препаратів - 41 од. Суттєво відстає від нього підприємство, що займає другу сходинку у рейтингу найбільших розробників - це ДП Херсонська біологічна фабрика, що входить до сфери відання Держпродспоживслужби. Кількість зареєстрованих ДП Херсонська біологічна фрабрика позицій становить 19 найменувань. На наступних щаблях розташовані ННЦ Інститут експериментальної і клінічної ветеринарної медицини (18 найменувань), ТОВ «Укрветпромпостач» (9 позицій) та ДП Сумська біологічна фрабрика (8 найменувань).

Перелік вітчизняних виробників препаратів налічує 29 підприємств. За кількістю препара- тів, які виробляються та обіг яких дозволено, у сегменті ветеринарних імунобіологічних препаратів вітчизняного виробництва п'ятірка лідерів сорормована такими підприємствами: ТОВ Біотестлаб-41 найменування; ДПХерсонська біологічна фрабрика - 27 найменувань; ТОВ «НДП «Ветеринарна медицина» - 21 найменування; ДП Сумська біологічна фрабрика - 17 найменувань; ТОВ «НДП «Ветеринарні біотехнології» 14 найменувань.

Вищенаведене дає підстави виділити трійку лідерів ринку ветеринарних імунобіологічних препаратів (як за кількістю розробок, так і препаратів, що виробляються): ТОВ Біотестлаб, ДП Херсонська біологічна фрабрика, ДП Сумська біологічна фрабрика.

Для характеристики тенденцій розвитку цих підприємств за 2019-2020 роки здійснено обчислення абсолютних та відносних показників зміни основних параметрів їх фрінансово-господарської діяльності (табл. 1).

Аналізуючи дані табл. 1, відзначимо, що очевидною $€$ суттєва позитивна динаміка більшості показників ТОВ Біотестлаб, а особливо: чистого доходу (+31,08\%); чистого прибутку (+317,02\%); валового прибутку (+ 169,83\%); рентабельності власного капіталу (+ 28,84 п.); рентабельності активів (+ 18,55 п.); вартості незавершених капітальних інвестицій (+ 44,28\%); вартості власного капіталу (+ 68,39\%). Натомість, ДП Сумська біологічна фрабрика та ДП Херсонська біологічна фрабрика демонструють негативну динаміку цих показників, суттєво нарощуючи короткострокові зобов'язання на тлі незначного зростання активів і, зокрема, оборотних (що можна трактувати як затарювання запасами). Далі дослідимо використання виділеними конкурентами цифрових технологій у маркетингу (табл. 2).

Коментуючи дані, наведені у табл. 2, відзначимо, що асортимент продукції визначено за переліком позицій у каталозі на сайті підприємств (ТОВ Біотестлаб-https://www.biotestlab.ua, ДП Сумська біологічна фрабрика - https://www. biofabrika.sumy.ua, ДП Херсонська біологічна фрабрика - http://khersonbiofabrika.com.ua/pronas/ - сайт не працює через закінчення терміну користування доменом). Під час характеристики активності у соціальних медіа було використано критерій представленості принаймні в одній мережі - у даному випадку Facebook - шляхом прямого пошуку відповідної сторінки та її аналізу.

Порівнюючи дані аналізованих підприємств (табл. 2), підкреслимо, що очевидним $€$ якісно 
Таблиця 1

\section{Динаміка основних показників фрінансово-господарської діяльності} підприємств-конкурентів у 2020 р. порівняно з 2019 р.

\begin{tabular}{|c|c|c|c|}
\hline Показник & $\begin{array}{c}\text { дП Сумська } \\
\text { біологічна } \\
\text { фабрика }\end{array}$ & $\begin{array}{c}\text { ДП } \\
\text { Херсонська } \\
\text { біологічна } \\
\text { фрабрика }\end{array}$ & $\begin{array}{c}\text { ТОВ } \\
\text { Біотестлаб }\end{array}$ \\
\hline Темп приросту вартості активів, \% & 6,49 & 9,31 & 30,44 \\
\hline $\begin{array}{l}\text { Темп приросту вартості оборотних } \\
\text { активів, \% }\end{array}$ & 25,75 & 9,14 & 46,93 \\
\hline $\begin{array}{l}\text { Темп приросту вартості необоротних } \\
\text { активів, \% }\end{array}$ & $-7,41$ & 9,53 & $-11,31$ \\
\hline Темп приросту вартості основних засобів, \% & $-4,64$ & 14,20 & $-33,60$ \\
\hline $\begin{array}{l}\text { Темп приросту вартості нематеріальних } \\
\text { активів, \% }\end{array}$ & $-20,10$ & 122,38 & $-26,74$ \\
\hline $\begin{array}{l}\text { Темп приросту вартості незавершених } \\
\text { капітальних інвестицій, \% }\end{array}$ & $-67,91$ & $-94,67$ & 44,28 \\
\hline $\begin{array}{l}\text { Темп приросту величини власного } \\
\text { капіталу, \% }\end{array}$ & 1,13 & $-13,61$ & 68,39 \\
\hline $\begin{array}{l}\text { Темп приросту величини довгострокових } \\
\text { зобов'язань, \% }\end{array}$ & 0,00 & 0,09 & 0,00 \\
\hline $\begin{array}{l}\text { Темп приросту величини } \\
\text { короткострокових зобов'язань, \% }\end{array}$ & 57,95 & 50,20 & $-10,33$ \\
\hline $\begin{array}{l}\text { Темп приросту величини собівартості } \\
\text { реалізованої продукції, \% }\end{array}$ & 0,25 & 10,37 & $-15,53$ \\
\hline $\begin{array}{l}\text { Темп приросту величини чистого доходу } \\
\text { від реалізації, \% }\end{array}$ & $-1,01$ & 0,89 & 31,08 \\
\hline $\begin{array}{l}\text { Темп приросту величини валового } \\
\text { прибутку, \% }\end{array}$ & $-3,08$ & $-10,97$ & 169,83 \\
\hline $\begin{array}{l}\text { Темп приросту величини чистого } \\
\text { прибутку, \% }\end{array}$ & $-54,39$ & $-69,34$ & 317,02 \\
\hline $\begin{array}{l}\text { Абсолютна зміна показника } \\
\text { рентабельності активів, пунктів }\end{array}$ & $-6,97$ & $-11,53$ & 18,55 \\
\hline $\begin{array}{l}\text { Абсолютна зміна показника } \\
\text { рентабельності власного капіталу, пунктів }\end{array}$ & $-8,22$ & $-19,72$ & 28,84 \\
\hline $\begin{array}{l}\text { Абсолютна зміна показника } \\
\text { рентабельності продажів, пунктів }\end{array}$ & $-3,96$ & $-4,04$ & 7,42 \\
\hline $\begin{array}{l}\text { Абсолютна зміна показника } \\
\text { фондовіддачі, пунктів }\end{array}$ & 0,13 & $-0,88$ & 15,53 \\
\hline $\begin{array}{l}\text { Абсолютна зміна коефріцієнта фрінансової } \\
\text { автономії, пунктів }\end{array}$ & $-0,05$ & $-0,12$ & 0,15 \\
\hline
\end{tabular}

Джерело: розрахунки авторів за даними [5]

інший рівень маркетингу, який демонструє ТОВ Біотестлаб. Підприємство забезпечує можливість придбання продукції через Інтернет-магазин (при цьому забезпечено широкий спектр можливостей доставки та оплати замовлення), майданчики дистриб'юторів та роздрібних торговців у мережі. Підприємство також має розвинуту мережу дистриб'юторів у 17 країнах світу. Причому кожен з них також має сайт, дані про який зазначено на сайті компанії. На сайті представлена значна кількість інструментів, орієнтованих на споживача - фрорми зворотного зв'язку у вигляді банерів, контакти для замовлення продукції та ін. Активною $€$ робота й у соціальних медіа. Так, кількість підписників підприємства y Facebook удвічі перевищує аналогічний показник для ДП Сумська біологічна фрабрика та у 900 разів - показник ДП Херсонської біологічної фрабрики.

Цисррові технології у маркетингу та комерції включають та охоплюють нові методи роботи компаній, які надають можливість сорормувати конкурентні переваги шляхом мінімізації видатків на взаємодію, збільшення ринків збуту і розвитку нових сфрер діяльності, кана- 
Таблиця 2

Характеристика маркетингової діяльності конкурентів за даними 2020 року (станом на 20 жовтня 2020 р.)

\begin{tabular}{|c|c|c|c|}
\hline Показник & $\begin{array}{c}\text { ДП Сумська } \\
\text { біологічна фрабрика }\end{array}$ & $\begin{array}{c}\text { ДП Херсонська } \\
\text { біологічна фрабрика }\end{array}$ & ТОВ Біотестлаб \\
\hline $\begin{array}{c}\text { Асортимент продукції, } \\
\text { од. }\end{array}$ & 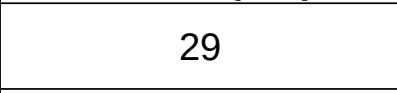 & немає даних & 121 \\
\hline $\begin{array}{c}\text { Система } \\
\text { (мережа збуту) }\end{array}$ & $\begin{array}{c}\text { наведені контакти } \\
\text { для замовлення та } \\
\text { співпраці на сайті }\end{array}$ & немає даних & $\begin{array}{c}\text { дані про дистриб'юторів } \\
\text { у } 17 \text { країнах на сайті; } \\
\text { мережа розширюєтья }\end{array}$ \\
\hline Наявність сайту & + & - & + \\
\hline $\begin{array}{c}\text { Представленість } \\
\text { у соціальних медіа }\end{array}$ & + & + & + \\
\hline $\begin{array}{l}\text { Кількість підписників } \\
\text { у соціальних медіа }\end{array}$ & 1378 & 3 & 2744 \\
\hline $\begin{array}{l}\text { Електронна торгівля } \\
\text { (інструменти) }\end{array}$ & $\begin{array}{c}\text { можна зробити } \\
\text { замовлення через } \\
\text { контакти на сайті; } \\
\text { майданчики } \\
\text { роздрібних торговців } \\
\text { в мережі }\end{array}$ & $\begin{array}{c}\text { майданчики } \\
\text { роздрібних торговців } \\
\text { в мережі }\end{array}$ & $\begin{array}{c}\text { інтернет-магазин; } \\
\text { майданчики } \\
\text { дистриб'юторів; } \\
\text { майданчики роздрібних } \\
\text { торговців в мережі; } \\
\text { замовлення через } \\
\text { контакти та фрорми } \\
\text { зворотного зв'язку } \\
\text { на сайті }\end{array}$ \\
\hline
\end{tabular}

Джерело: результати власних досліджень авторів

за даними офріційних веб-сторінок та сторінок підприємств у Facebook

лів збуту та ін. Існує ряд особливостей електронного бізнесу, які змінюють стратегії маркетингу [4]: незалежність (відсутність впливу) виробника і споживача; доступність 24/7; можливість швидкого огляду більшої кількості пропозицій товарів на ринку. За таких умов, вимоги до стратегії маркетингу та, особливо, електронного маркетингу, мають бути переглянуті з урахуванням таких позицій: необхідність кращого позиціонування, частіших показів для споживача, більш ефективний та помітний дизайн та реклама тощо.

Слід зазначити, що цифровий маркетинг це не лише створений сайт та сторінка у соціальних медіа, реклама, а цілісний комплекс робіт, який включає аналітику та оптимізацію веб-сторінок, спрямовані на збільшення кількості показів сайту в мережі, збільшення трафріку та ефрективних показів на сайті. Саме трафрік - кількість відвідувачів сайту - $€$ головним мірилом результативності цисррового маркетингу та маркетингової стратегії підприємства загалом за сучасних умов. Для профресійної оцінки та аналізу сайту може бути використаний широкий спектр інструментів аналітичних засобів, серед яких можна вказати на такі: Semrush, Be1.ru, Alexa та ін.

Використовуючи засоби Semrush було проаналізовано динаміку трафріку та ключові слова сайтів конкурентів - ТОВ «Біотестлаб» та ДП Сумська біологічна фрабрика. Результати проведеного дослідження $€$ такими:

1) за даними березня 2020 р., органічний трафрік сайту ТОВ Біотестлаб становив 1350 користувачів, а ДП Сумська біологічна фрабрика - 1, а у березні 2021 року - 2990 та 6 користувачів, відповідно;

2) кількість ключових слів сайту ТОВ Біотестлаб, що забезпечують потрапляння сайту у три перші позиції пошукової видачі становить 56 одиниць, у 4-10 позиції - 30 одиниць, тоді як для ДП Сумська біологічна фрабрика ключові слова, які б забезпечували потрапляння сайту у перші 10 позицій пошукової видачі, не ідентифріковані.

Отримані результати свідчать про те, що невід'ємною складовою успішності цисррового маркетингу є належна робота щодо аналізу та оптимізації сайту з використанням інструментів SEO (Search Engine Optimization). Таким чином, підвищенню конкурентоспроможності підприємства в сучасних умовах розвитку ринку ветеринарних імунобіологічних препаратів значною мірою сприятиме: 1) ретельний аналіз та удосконалення дизайну сайту; 2) SEO сайту; 3) постійний моніторинг та аналітика трафріку сайту та його ефективності; 4) розробка інтернет-магазину на сайті; 5) розробка та імплементація інструментів зворотного зв'язку на сайті (банери); 6) пошук партнерських організацій та 
укладання угод щодо реклами сайту; 7) вдосконалення контенту сайту (слід зробити його більш цікавим, пізнавальним).

Висновки. Результати проведеного дослідження дають підстави стверджувати, що цифрровий маркетинг є суттєвим чинником успіху на ринку ветеринарних імунобіологічних препаратів України. В умовах пандемічних обмежень, лише одному підприємству 3 трійки лідерів ринку вдалось не лише забезпечити стабільність показників фрінансово-господарської діяльності, а й суттєво їх покращити. Відмітною особливістю цього підприємства $€$ активний розвиток цифрових технологій у маркетингу, у тому числі - оптимальні параметри налаштувань веб-сторінки, що забезпечують краще позиціонування підприємства серед конкурентів у мережі Інтернет. Оцінюючи вплив цифрового маркетингу на результати господарювання, можна вказати на те, що продажі ТОВ Біотестлаб у рік найбільш жорстких пандемічних обмежень (2020р.) зросли на більш ніж 30\%, порівняно 3 попереднім періодом і значна роль у цьому, на наш погляд, належить цифровим технологіям у маркетинговій діяльності. Отримані результати можуть бути використані суб'єктами ринку для вдосконалення власної діяльності та свідчать про необхідність запровадження нових сучасних підходів, зміни фрілософрії бізнесу на державних підприємствах, особливо в сорері маркетингу та використання цифрових технологій. Це може становити предмет подальших досліджень у цій сфері.

\section{СПИСОК ВИКОРИСТАНИХ ДЖЕРЕЛ:}

1. Бушуєва І.В., Борисенко Н.М. Ритейл ветеринарних імунобіологічних препаратів на українському ринку ветеринарних вакцин. Актуальні питання фрармацевтичної та медичної науки та практики. 2020. № 1. DOI: https://doi.org/10.14739/2409-2932.2020.1.198188

2. Гальчинська Є.К., Сорокіна Н.Г. Аналіз вітчизняного ринку ветеринарних імунобіологічних засобів для дрібних тварин. Український часопис ветеринарних наук. 2019. № 10(3). DOI: https://doi.org/10.31548/ ujvs2019.03.009

3. Гарвас Г.Д., Колодійчук В.А. Особливості оцінки конкурентоспроможності ветеринарних препаратів. Науковий вісник Львівського національного університету ветеринарної медицини та біотехнологій імені С.3. Ґжицького. 2019. № 93(2). URL: https://cyberleninka.ru/article/n/osoblivosti-otsinki-konkurentospromozhnostiveterinarnih-preparativ (дата звернення: 29.10.2021).

4. Єремеєва Н.С., Зозульов О.В. Особливості електронного бізнесу на ринку ветеринарних препаратів. Економічний вісник НТУУ «КПI». 2017. № 14. C. 299-306. DOI: https://doi.org/10.20535/2307-5651.14.2017.108740

5. Звітність українських підприємств. URL: https://zvitnist.com (дата звернення: 20.10.2021).

6. Немченко А.С., Полова Ж.М., Назаркіна В.М., Сімонян Л.С. Маркетингові дослідження ринку ветеринарних лікарських засобів, що застосовуються при лікуванні маститу великої рогатої худоби. Управління, економіка та забезпечення якості в фармації. 2017. № 2(50). DOI: https://doi.org/10.24959/uekj.17.17

7. Перелік ветеринарних імунобіологічних препаратів, що зареєстровані в Україні станом на 13.04.2021 p. URL: https://dpss.gov.ua/storage/app/sites/12/СтруктурніПідрозділи/Департамент\%20безпечності\%20харчових \%20продуктів\%20та\%20ветеринарної\%20медицини/відділ\%20ліцензування/17072020.xls (дата звернення: 20.10.2021).

8. Симоненко К. Все буде онлайн: як рітейлери переходять в інтернет через карантин. 2021. URL: https://rau.ua/novyni/novini-kompanij/ritejlery-perehodyat-v-internet/ (дата звернення: 20.10.2021).

\section{REFERENCES:}

1. Bushuieva I.V., Borysenko N.M. (2020) Ryteil veterynarnykh imunobiolohichnykh preparativ na ukrainskomu rynku veterynarnykh vaktsyn [Retail of veterinary immunobiological drugs on the Ukrainian market of veterinary vaccines]. Current issues of pharmaceutical and medical science and practice, vol. 1. DOI: https://doi.org/10.14739 /2409-2932.2020.1.198188

2. Halchynska Ye. K., Sorokina N.H. (2019) Analiz vitchyznianoho rynku veterynarnykh imunobiolohichnykh zasobiv dlia dribnykh tvaryn [Analysis of the domestic market of veterinary immunobiological means for small animals]. Ukrainian Journal of Veterinary Sciences, vol. 10(3). DOI: https://doi.org/10.31548/ujvs2019.03.009

3. Harvas H.D., Kolodiichuk V.A. (2019) Osoblyvosti otsinky konkurentospromozhnosti veterynarnykh preparativ [Features of assessing the competitiveness of veterinary drugs]. Scientific Bulletin of Lviv National University of Veterinary Medicine and Biotechnology named after Gzhitsky S.Z., vol. 93(2). Available at: https://cyberleninka.ru/ article/n/osoblivosti-otsinki-konkurentospromozhnosti-veterinarnih-preparativ (accessed 29 October 2021). 
4. Yeremeieva N.S., Zozulov O.V. (2017) Osoblyvosti elektronnoho biznesu na rynku veterynarnykh preparativ [Features of e-business in the market of veterinary drugs]. Economic Bulletin of NTUU "KPI", vol. 14, pp. $299-306$. DOI: https://doi.org/10.20535/2307-5651.14.2017.108740

5. Zvitnist ukrainskykh pidpryiemstv [Reports of Ukrainian enterprises]. Available at: https://zvitnist.com (accessed 20 October 2021).

6. Nemchenko A.S., Polova Zh.M., Nazarkina V.M., Simonian L.S. (2017) Marketynhovi doslidzhennia rynku veterynarnykh likarskykh zasobiv, shcho zastosovuiutsia pry likuvanni mastytu velykoi rohatoi khudoby [Marketing research of the market of veterinary drugs used in the treatment of mastitis of cattle]. Management, Economics and Quality Assurance in Pharmacy, vol. 2(50). DOI: https://doi.org/10.24959/uekj.17.17

7. Perelik veterynarnykh imunobiolohichnykh preparativ, shcho zareiestrovani v Ukraini stanom na 13.04.2021 r. [List of veterinary immunobiological drugs registered in Ukraine as of April 13, 2021]. Available at: https://dpss.gov.ua/ storage/app/sites/12/StrukturniPidrozdily/Departament\%20bezpechnosti\%20kharchovykh\%20produktiv\%20ta\%20 veterynarnoi\%20medytsyny/viddil\%20litsenzuvannia/17072020.xls (accessed 20 October 2021).

8. Symonenko K. (2020) Vse bude onlain: yak riteilery perekhodiat v internet cherez karantyn [Everything will be online: how retailers go online through quarantine]. Available at: https://rau.ua/novyni/novini-kompanij/ritejlery-perehodyat-v-internet/. (accessed 20 October 2021). 